\title{
Differences in Deficiencies
}

\author{
Roxane Ducloux $\cdot$ Jean-Jacques Altman
}

Published online: 11 May 2011

(C) Springer Science+Business Media, LLC 2011

Dear Dr. Van der Schueren and colleagues,

We would like to thank you for your attentive lecture of our article on hypovitaminosis D before bariatric surgery in French obese patients [1]. Your comments and analysis are very appealing [2].

With the same cut-off level of 25-OH-vitamin D, you found in your cohort only $65 \%$ deficient patients while we counted $96 \%$. Your findings are congruent with the other American articles we quoted, which established between $57 \%$ and $61 \%$ hypovitaminosis D [3-5].

We agree that ethnicity does not seem to explain the difference between our results. On the contrary, the ethnic pattern of your population induced a greater risk of vitamin D deficiency, since a darker skin reduces the dermal synthesis of vitamin D. With 30\% Afro-American patients in your cohort versus $10 \%$ of African people in ours, and $27 \%$ Caucasian versus $52 \%$, we could indeed have expected a lower rate of deficiency in our cohort.

Sun exposure may not be a contributive factor for two main reasons. First, both our cohorts are urban, with most patients doing indoor jobs and leisure activities. Second, hours of sunshine do not seem to be much different between New York (around 2,000 $\mathrm{h}$ a year) and Paris (around 1,800 h).

Concerning the type of assay, we are not sure that it can explain the difference between our populations. If we increase by $15 \%$ to $25 \%$ our vitamin D data to standardize the results, we still find between $72 \%$ and $82 \%$ deficiency.

Besides, it would be interesting to compare mean body mass index in both cohorts: as we mentioned in our article,

a part of low serum rate seems to be due to vitamin trapping in adipose tissue, the higher the IMC, the lower the $25-\mathrm{OH}-$ vitamin D level.

In conclusion, it may be that American obese people are better than the French concerning nutritional supplements taken before bariatric surgery. Nevertheless, in both countries, more than half of the patients undergoing bariatric surgery are already lacking of vitamin D. Never mind the differences, we agree about the need of implementing guidelines and close monitoring of nutritional status.

Conflicts of interest None.

\section{References}

1. Ducloux R, Nobécourt E, Chevalier JM, et al. Vitamin D deficiency before bariatric surgery: should supplement intake be routinely prescribed? Obes Surg. 2011;21(5):556-60.

2. Van der Schueren BJ, Green N, Gorroochurn P, et al. Low vitamin $\mathrm{D}$ in candidates for bariatric surgery: are the Americans better off than the French? Obes Surg. 2011; in press

3. Goldner WS, Stoner JA, Thompson J, et al. Prevalence of vitamin D insufficiency and deficiency in morbidly obese patients: a comparison with non-obese controls. Obes Surg. 2008;18(2):145-50.

4. Carlin AM, Rao DS, Meslemani AM, et al. Prevalence of vitamin $\mathrm{D}$ depletion among morbidly obese patients seeking gastric bypass surgery. Surg Obes Relat Dis. 2006;2(2):98-103.

5. Gemmel K, Santry HP, Prachand VN, et al. Vitamin D deficiency in preoperative bariatric surgery patients. Surg Obes Relat Dis. 2009;5 (1):54-9.

R. Ducloux $(\triangle) \cdot$ J.-J. Altman

Hôpital Européen Georges Pompidou,

Service de Diabétologie-Endocrinologie-Nutrition,

Université Paris V Descartes,

Paris, France

e-mail: roxane.ducloux@egp.aphp.fr 